\title{
The Computational Fluid Dynamics (CFD) Analysis of the Pressure Sensor Used in Pulse-Operated Low-Pressure Gas-Phase Solenoid Valve Measurements
}

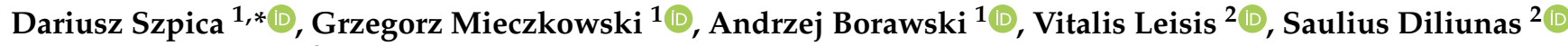 \\ and Tilmute Pilkaite ${ }^{2}$ \\ 1 Faculty of Mechanical Engineering, Bialystok University of Technology, 45C Wiejska Str., \\ PL-15351 Bialystok, Poland; g.mieczkowski@pb.edu.pl (G.M.); a.borawski@pb.edu.pl (A.B.) \\ 2 Faculty of Mechanical Engineering and Design, Kaunas University of Technology, 56 Studentu Str., \\ LT-50240 Kaunas, Lithuania; vitalis.leisis@ktu.lt (V.L.); saulius.diliunas@ktu.lt (S.D.); \\ tilmute.pilkaite@ktu.lt (T.P.) \\ * Correspondence: d.szpica@pb.edu.pl
}

check for updates

Citation: Szpica, D.; Mieczkowski, G.; Borawski, A.; Leisis, V.; Diliunas, S.; Pilkaite, T. The Computational Fluid Dynamics (CFD) Analysis of the Pressure Sensor Used in PulseOperated Low-Pressure Gas-Phase Solenoid Valve Measurements. Sensors 2021, 21, 8287. https:// doi.org/10.3390/s21248287

Academic Editor: Uwe Hampel

Received: 2 November 2021

Accepted: 9 December 2021

Published: 11 December 2021

Publisher's Note: MDPI stays neutral with regard to jurisdictional claims in published maps and institutional affiliations.

Copyright: (C) 2021 by the authors. Licensee MDPI, Basel, Switzerland. This article is an open access article distributed under the terms and conditions of the Creative Commons Attribution (CC BY) license (https:// creativecommons.org/licenses/by/ $4.0 /)$.

\begin{abstract}
This paper presents a flow analysis of the original pressure sensor used to determine times until full opening and closing of the pulse-operated low-pressure gas-phase solenoid valve. The sensor in question, due to the fast variation of the process lasting several milliseconds, has high requirements in terms of response time and ability to identify characteristic parameters. A CFD code has been employed to successfully model the flow behavior of the original pressure sensor used to determine times until full opening and closing of the pulse-operated low-pressure gas-phase solenoid valve at different inlet flow conditions, using the Eulerian multiphase model, established on the Euler-Euler approach, implemented in the commercial CFD package ANSYS Fluent. The results of the modelling were validated against the experimental data and also give more comprehensive information on the flow, such as the plunger displacement waveform. The flow calculations were dynamic in nature; therefore, the experimental plunger displacement waveforms were entered as input in the software for dynamic mash implementation. In identifying the times until full opening and closing, the characteristic points of the pressure waveform on the pressure sensor plate were adopted. CFD flow calculations confirmed the accuracy of identifying the times until full opening and closing by relating them to the results from the plunger displacement sensor. The validation of the results of calculations with the analyzed sensor and the original stand also confirmed the correctness of the use of this type of method for the assessment of gas injector operating times. In the case of time until full opening, the CFD calculations were shown to be consistent with experimental tests, with only a few cases where the relative difference with respect to the displacement sensor reached 3\%. The situation was slightly worse in the case of time until full closing, where the results of CFD calculations were in agreement with the displacement sensor, while the experimental test stands had a relative difference of up to $21 \%$. It should be remembered that the sensor evaluates times below $5 \times 10^{-3} \mathrm{~s}$, and its construction and response time determine the use depending on the adopted level of accuracy.
\end{abstract}

Keywords: mechanical engineering; supply system; computational fluid dynamics (CFD); pressure sensor; solenoid valve; research

\section{Introduction}

Recently, hybrid [1] and electric [2,3] propulsion systems have been increasing in transportation modes. There is advanced work on pneumatic engines and air-assisted combustion engines [4-6]. Hybrid and electric drives have many advantages, including higher propulsion flexibility as well as reduced emissions of harmful exhaust components [7]. However, the latter is dependent on how electricity is produced, where emissions are in 
many cases only relocated. The hydrogen cell is projected to be the most future-proof type of propulsion $[8,9]$. Work on the use of alternative fuels in classical internal combustion engines also continues unabated. These efforts are aimed at reducing $\mathrm{CO}_{2}$ emissions [10] by using fuels with lower carbon content. In addition, modifications are carried out in the area of combustion process organization, where controlled auto-ignition (CAI)/homogeneous charge compression ignition (HCCI) [11,12], high-pressure direct injection (HPDI), or reactivity-controlled compression ignition (RCCI) [13] can be mentioned as main groups. Work is also underway to further develop multi-fuel internal combustion engines [14]. However, one uncertainty is still the emission limitations of the Euro 7 standard $[15,16]$; according to which, perhaps the internal combustion engine as the sole source of propulsion will not be able to meet in the future.

The most common gaseous fuels used in internal combustion engines are liquefied petroleum gas (LPG) and compressed natural gas (CNG). Alternative fuels are included in the European Union Directive (2014/94/EU) [17]. LPG and CNG have applications in car engines [18,19], work machinery [20,21], and ships [22,23]. In land transport, cars powered by spark-ignition (SI) engines most often use LPG vapor phase power systems [24]. Despite the fact that the development of internal combustion engines and the subsequent emission restrictions have directed LPG supply systems towards liquid-phase injection [18], still a large proportion of engines are powered by vapor phase [25]. Some novelty is the attempts to convert SI engines, which are part of a hybrid power train, to run on vapor-phase LPG [26].

Commercially available LPG vapor-phase systems have a very similar design. Each of them includes an executive element in the form of the low-pressure gas-phase injector. The functioning of the system depends mainly on this element, and a quick assessment of its operational state is a great research challenge.

In experimental studies of the low-pressure gas-phase injectors, a flow meter is mostly used and flow characteristics are determined based on volumetric flow rate $[27,28]$. There are also attempts to use gasoline injector test benches to determine the flow characteristics of gas injectors [29]. However, using a liquid working medium to test gas injectors is not able to properly reflect the flow characteristics. A rather innovative test method for gas injectors is presented in [29], where the so-called 'fuel tank refill' method was used to determine the flow characteristics. The method presented there is an indirect method, where in place of a flow meter, fixed volume tanks are used to act as a flow meter. Based on the pressure variations in the tanks and the simplified flow model (lumped method), the flow parameters are identified numerically. In addition to the flow characteristics, it is possible to evaluate the fuel dosage irregularity of the injection units. A simplified method for evaluating fuel dosage irregularity is presented in [30] using U-tube manometers. Knowledge of the flow characteristics is essential for the proper configuration of the gas supply system and directly affects the external parameters and toxicity of the engine exhaust [31-34]. It is also very often necessary to determine time until full opening and closing of the gas injectors. Indirect non-invasive methods can be used for this purpose in the simplest variant. The course analyzed are voltage and current in the power line [35-37], acceleration sensors the corps of the injector $[27,36]$, flow meters in flow line $[27,38]$, and pressure sensors in the outlet nozzle [39]. The pressure sensors in the outlet nozzle are also used to assess fuel dosage non-repeatability [40]. Apart from that, direct methods are used, which, however, require interference in the injector's executive system in order to install the displacement sensor measuring needle $[36,41]$ or the needle used in image recording with a high-speed camera [42]. A number of optical sensors, including laser sensors, have also been developed and used in research to enable non-contact measurement of spire elevation [43-45]. However, needle/plunger conditions preventing access may be an obstacle here.

Knowledge of time until full opening and closing of the gas-phase injectors is very important for the configuration of the gas supply system, as it influences the gas injection angle and requires appropriate corrections in the control algorithm. Therefore, in the 
software options for the configuration of the gas supply system there are fields for selecting the injector (type/model) [46]. For a more in-depth analysis of the injection process outside the injector, methods used in liquid fuel injector testing can be used. The most common are image analysis methods with high-speed cameras [47-50], light fluorescence absorption [51,52], heat flow sensors [53], and optical sensors [54,55]. Measurement techniques using optical laser [52,56,57], phase Doppler particle analyzer (PDPA) system [58], tomographic PIV method [59-61] are also used. The possibility of using the methods used in liquid fuel injector testing to test gas injectors is determined by the identification procedures and their applicability in gas flow evaluation. It should also be kept in mind that very often gas injectors are tested using air instead of the target gas for safety reasons. Additionally, values for operating parameters such as volumetric flow rate, time until full opening and closing are provided by manufacturers for air. However, a full functional evaluation can be carried out for the target gas.

The computational fluid dynamics (CFD) is one of the most widely used methods for functional evaluation of pressure, flow, and temperature sensors. The calculations are based on the Reynolds averaged Navier-Stokes (RANS) approach. In addition to the quantitative evaluation to validate the calculations, CFD calculations also allow for a qualitative assessment of the flow. The qualitative assessment, very often difficult or impossible to validate, allows for the establishment of guidelines for the installation or design of sensor connections. In [62] an integrated air pressure and flow sensor is presented. In this case, CFD was used to visualize the flow inside the sensor, with performance prediction in Coventorware based on CFD. In the experimental study, a pressure sensitivity of $1.3 \mathrm{~V}^{-3} \cdot \mathrm{mmHg}^{-1}$ (range $\left.(0-50) \times 10^{3} \mathrm{~Pa}\right)$ was obtained at flow rates of $(0 \ldots .5) \mathrm{L} \cdot \mathrm{min}^{-1}$. The analysis of a capacitive fluid flow sensor is presented in [63]. Using CFD, the input parameters in the form of pressure and velocity were changed to investigate the hydrodynamic parameters. Thus, the geometric parameters of the sensor electrode copula were determined considering the capacitive rest.

Very often there is a need to evaluate the impact of sensor development on their measurement capabilities. The estimation of a pressure response function in a dry seal system and a dynamic pressure measurement for monitoring the seal film pressure is presented in [64]. The response function obtained from the analyses helped to correct for the dynamic pressure effects due to damping. The length of the flexible connection hose was determined to be $115 \mathrm{~mm}$, and the seal spiral grooves were optimized for an inlet angle of $15^{\circ}$ and $11^{\circ}$. The calculations are also carried out within separate sections of one sensor. In [65], the effect of separation between two parts of a highly sensitive airflow sensor was analyzed. As a result, the measurement accuracy was improved over conventional measurement systems. CFD calculations show their applicability also with analysis of liquid-liquid flows with high viscosity coefficient. In [66], OpenFOAM and a one-dimensional model were used for CFD, while the RANS model was used for turbulence. Validation of the calculations showed good agreement for pressure drop, volume fractions, and phase distribution. Additionally, the agreement of CFD results with experimental pressure and temperature studies is presented in [67], where the analyses focused on a blunt cone (30 apex-angle and $51 \mathrm{~mm}$ base diameter) at wind flow speeds of Mach 6.5 and 8.35 (300 $\mathrm{mm}$ hypersonic wind tunnel). In the experimental study using fiber Bragg grating (FBG). The analysis of flow mechanisms related to its aggressiveness was presented in [68]. CFD calculations were validated using piezoelectric polyvinylidene fluoride (PVDF) probes by varying operating frequencies and gaps and shielding. A functional analysis of a sensor built similar to a Prandtl tube is presented in [69]. The analysis of the main sensor operating parameters inferred from the CFD calculations was confirmed in the course of wind tunnel experiments.

Some of the analyses also focus on automotive technology. Trends set by downsizing, downspeeding and the increase in the compression ratio resulted in the evaluation of the influence of selected factors on the combustion process. In [70], using RANS in CFD, the combustion process was analyzed and reflected in the pressure trace recorded by the 
sensor. The statistical analysis of the indices proposed in the study allowed predicting the possibility of knocking combustion. Moreover, numerical prediction of exhaust emissions has become a certain computational direction in the automotive industry. In [71], a model for predicting nitrogen oxides $\left(\mathrm{NO}_{\mathrm{x}}\right)$ emissions in a diesel engine was presented using CFD and a physical model. By validating the calculations with experimental studies, the applicability of the former was demonstrated. It was also found that the proposed predictive model is applicable to 1-D simulations (GT-SUITE, and AMESIM) giving similar results to 3-D CFD. The use of CFD to analyze in automotive lambda sensor pressures allowed the estimation of the sensor protective wall life [72]. Modifications to the probe design reduced the inlet pressure by $1.4 \%$, outlet pressure by $9.8 \%$, exhaust gas velocity by $19.37 \%$ and $17.1 \%$ respectively, and temperature inside the measurement chamber by $15 \%$. In conclusion, it was found that the proposed modifications will increase its lifetime. Combining CFD (RANS) models with semi-empirical aeroacoustic models is presented in [73], where the performance of automotive axial fans was analyzed to reduce airflow noise. The applicability of the proposed model description was demonstrated for frequencies of (100-2000) $\mathrm{Hz}$ as well as (2-10) kHz.

Simulations using CFD are also applied to the analysis of microflow sensor in medicine. The microflow sensor, proposed in [74], was numerically investigated for the effect of its placement in different areas of the human aorta on blood flow characteristics. A $10 \%$ increase in blood flow velocity was demonstrated in a cross-section of sensor placement. The presence of the catheter caused a decrease in blood pressure to $768 \mathrm{~Pa}$, and less than $30 \%$ of the arterial cross-sectional area experienced an increase in temperature.

The aim of this study was a CFD flow analysis of an original pressure sensor used to determine times until full opening and closing of the low-pressure gas-phase solenoid injector. Literature reports indicate the possibility of using this type of sensor as an indirect method for experimental determination of times until full opening and closing $[28,36,39]$ and dosage non-repeatability [40]. However, there is a lack of flow analysis, where it would be possible to use dedicated software to determine the pressure waveform on the measuring surface of the sensor during dynamic opening and closing of the solenoid valve. Based on the pressure waveform, times until full opening and closing could be determined in a non-invasive way, without interference with the operating system, i.e., the plunger. The validation of the CFD calculation results with the experimental results allowed the evaluation of the measurement capability of the presented sensor and the indication of obtained discrepancies, which should be taken into account when using it.

\section{Materials and Methods}

\subsection{The Analysed Sensor}

The object of analysis was the original sensor (Figure 1) used for measuring the pressure at the outlet of a low-pressure gas-phase injector. The main task of this sensor is to measure the rapidly varying pressure at the outlet of a pulsed solenoid valve nozzle. Based on the pressure waveform recorded during the opening and closing of the solenoid valve, the values of functional parameters such as times until full opening and closing can be determined. Apart from times until full opening and closing, the uniqueness of successive opening cycles can also be determined using the area under the pressure curve or the average pressure in a cycle. Measurement capabilities of the presented sensor in experimental conditions have been presented by the author in many publications, including $[28,39]$.

The operation of the sensor is as follows. When the tested low-pressure solenoid valve is opened, air flows through the inlet nozzle into the blow-by hole in the upper housing. In the lower housing a pressure sensor MPXH6400A was mounted. The blow-by holes in upper housing were intended to allow air to flow out of the measuring chamber with the pressure sensor. In the absence of the blow-by holes, the pressure in the chamber would continue to rise, which would prevent the sensor from functioning properly. It was possible to move the pressure sensor using the lower-upper housings threaded connection. Nut 1 
was used to lock the threaded connection. Nut 2 was used to attach the pulsation damper. In Figure 1 only part of the pulsation damper is shown due to the large size of the other components. At the bottom of the sensor was the electrical connection for connecting to a power source and sending voltage to the recording device. The power source was a $12 \mathrm{~V}$ car battery, which helped to reduce noise during the measurement. An oscilloscope was used to record the courses. The description of the sensor's measurement capabilities will be presented later in this paper.

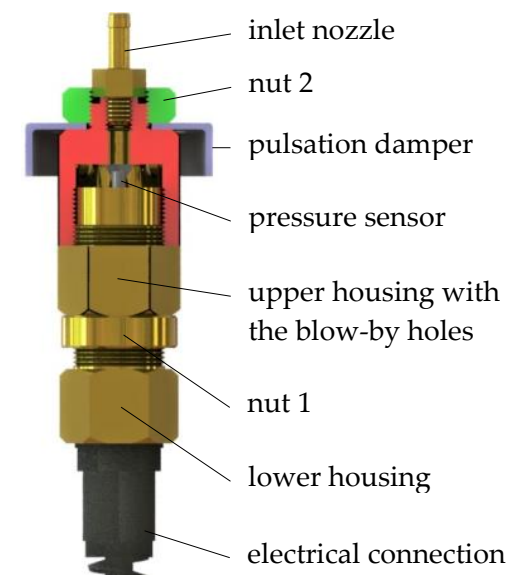

Figure 1. The CAD model of the analyzed sensor.

The technical data of the MPXH6400A pressure sensor are presented in Table 1.

Table 1. The technical data of the MPXH6400A sensor [75].

\begin{tabular}{cc}
\hline Parameter & Value \\
\hline Nozzle size & $4 \times 10^{-3} \mathrm{~m}$ \\
Pressure range & $(20 \ldots 400) \times 10^{3} \mathrm{~Pa}$ \\
Max. pressure & $1600 \times 10^{3} \mathrm{~Pa}$ \\
Storage temperature & $(-40 \ldots+125)+273.15 \mathrm{~K}$ \\
Supply voltage & $(4.64 \ldots 5.36) \mathrm{V}$ \\
Supply current & $3 \times 10^{-3} \mathrm{~A}$ \\
Accuracy (0 . . 85 $\left.{ }^{\circ} \mathrm{C}\right)$ & $\pm 1.5^{\circ}$ \\
Sensitivity $\left.^{-3} \mathrm{Va}\right)$ & $12.1\left(10^{-3} \mathrm{~V} / 10^{3} \mathrm{~Pa}\right)$ \\
Response time & $<1.0 \times 10^{-3} \mathrm{~S}$ \\
Warm-up time & $20 \times 10^{-3} \mathrm{~S}$ \\
Offset stability & $\pm 0.25 \% \mathrm{~V}$ \\
\hline
\end{tabular}

\subsection{The Tested Low-Pressure Gas-Phase Solenoid Valve}

In order to analyze the performance of the sensor shown in Figure 1, the Valtek Rail Type-30 low-pressure gas-phase injector (Figure 2) was taken as the tested electro valve. This is one of the most popular gas injectors allowing pulse operation. In addition, it allowed easy installation of a displacement sensor to determine the displacement of the piston during the opening and closing phases.

The operation of the solenoid valve is as follows. In the state without electric power, the solenoid valve is closed, the plunger is pressed against the corps by the spring. When an electrical pulse is applied to the coil terminals and the solenoid circuit is closed with the cramp, the plunger overcomes the spring force and the solenoid valve opens. Air begins to flow from the inlet nozzle toward the outlet nozzle. The plunger moves until it contacts the limiter (the limiter sets the maximum stroke). When the electrical impulse at the coil terminals disappears, the electromagnetic field disappears, and the plunger moves toward closure pressed by the spring. The plunger on the corps side and the limiter are equipped with rubber elements to dampen impacts. 


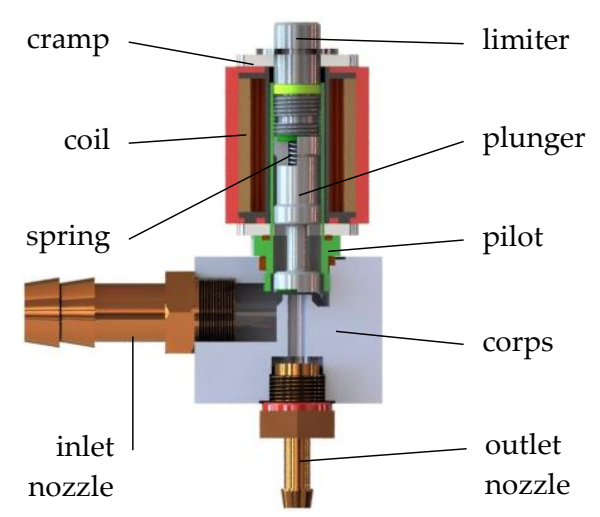

Figure 2. The CAD model of the tested solenoid valve (Valtek Rail Type-30 impulse gas-phase injector).

The technical data of the tested injector Valtek Rail Type-30 are presented in Table 2.

Table 2. The technical data of the Valtek Rail Type-30 injector [76].

\begin{tabular}{cc}
\hline Parameter & Value \\
\hline Nozzle size & $4 \times 10^{-3} \mathrm{~m}$ \\
Piston stroke & $0.4 \times 10^{-3} \mathrm{~m}$ \\
Coil resistance & $3 \Omega$ \\
Time until full opening & $3.4 \times 10^{-3} \mathrm{~s}$ \\
Time until full closing & $2.2 \times 10^{-3} \mathrm{~s}$ \\
Max. working pressure & $4.5 \times 10^{3} \mathrm{~Pa}$ \\
Operating temperature & $(-20 \ldots+120)+273.15 \mathrm{~K}$ \\
\hline
\end{tabular}

\subsection{The Flow Analysis}

Ansys Fluent software was used to carry out flow analysis of the gas injector-pressure sensor system under study. This software is widely used in the evaluation of flow processes. In the case presented in this paper, the Reynolds average Navier-Stokes (RANS) approach [77] was used. In this approach, the Reynolds distribution model is substituted into the Navier-Stokes equation resulting in continuity and momentum equations of the form Equations (1) and (2) for incompressible flow:

$$
\begin{gathered}
\frac{\partial u_{i}}{\partial x_{i}}=0 \\
\rho\left(\frac{\partial u_{i}}{\partial t}+\frac{\partial u_{i} u_{j}}{\partial x_{j}}\right)=-\frac{\partial p}{\partial x_{i}}+\frac{\partial}{\partial x_{i}}\left(\mu\left(\frac{\partial u_{i}}{\partial x_{j}}+\frac{\partial u_{j}}{\partial x_{i}}-\frac{2}{3} \delta_{i j} \frac{\partial u_{l}}{\partial x_{l}}\right)\right)+\frac{\partial}{\partial x_{i}}\left(-\rho \overline{u_{i}^{\prime} u_{j}^{\prime}}\right) .
\end{gathered}
$$

where $u_{i}$ and $u_{j}$ are the mean velocities; $u_{i}^{\prime}$ and $u_{j}^{\prime}$ are the fluctuating part of the velocity; $p$ is the dynamic pressure; $\delta_{i j}$ is the Kronecker delta; and $\rho$ is the fluid density.

The last term in brackets in Equation (2) represents the Reynolds stress. As this is unknown, the equations are open. The Boussinesq approximation of Equation (3) is used to solve this problem:

$$
-\rho \overline{u_{i}^{\prime} u_{j}^{\prime}}=\mu_{t}\left(\frac{\partial u_{i}}{\partial x_{j}}+\frac{\partial u_{j}}{\partial x_{i}}\right)-\frac{2}{3}\left(\rho k+\mu_{t} \frac{\partial u_{k}}{\partial x_{k}}\right) \delta_{i j},
$$

where $\mu_{t}$ is the turbulent viscosity; $k$ is the kinetic energy of turbulence.

The turbulent viscosity $\mu_{t}$ can be obtained by solving additional transport equations. The number of additional transport equations depends on the turbulence model chosen. 
In this study, the $k-\omega$ SST model was decided upon. This model combines the $k-\varepsilon$ and $k-\omega$ turbulence models [78]. The transport equations take the form of Equations (4) and (5):

$$
\begin{gathered}
\rho\left(\frac{\partial}{\partial t} k+\frac{\partial}{\partial x_{i}}\left(k u_{i}\right)\right)=\frac{\partial}{\partial x_{j}}\left(\Gamma_{k} \frac{\partial k}{\partial x_{j}}\right)+\widetilde{G}_{k}-Y_{k} \\
\rho\left(\frac{\partial}{\partial t} \omega+\frac{\partial}{\partial x_{i}}\left(\omega u_{i}\right)\right)=\frac{\partial}{\partial x_{j}}\left(\Gamma_{k} \frac{\partial \omega}{\partial x_{j}}\right)+G_{\omega}-Y_{\omega}+D_{\omega} .
\end{gathered}
$$

where $\widetilde{G}_{k}$ and $G_{\omega}$ represent the production terms of $k$ and $\omega ; Y_{k}$ and $Y_{\omega}$ represent the dissipation terms of $k$ and $\omega ; \Gamma_{k}$ and $\Gamma_{\omega}$ represents the effective diffusivity of $k$, and $\omega ; D_{\omega}$ represents the cross-diffusion term.

Analyses conducted by many researchers as well as commercial software developers to assess the applicability of the $k-\varepsilon$ and $k-\omega$ turbulence models to describe flows have led to some general conclusions. The $k-\varepsilon$ model correctly represents the free flow and the boundary layer. It is also characterized by low sensitivity to feed conditions with respect to the quantities describing turbulence. The $k-\omega$ model, on the other hand, is considered to be the one that more closely represents turbulent flow in the near-wall layer. Additionally, it is characterized by high sensitivity with respect to the quantities describing turbulence in free flow. Therefore, in the analyzed case of flow tests of an injector and a pressure sensor, where we have a large range of flow cross-section and length values, it was considered appropriate to combine both turbulence models.

For the calculations, a solid model of the fluid was created (Figure 3a) including a division into sections where initial and boundary conditions could be determined. The division into sections also made it possible to vary the type and density of the mesh. Of course, the compatibility of the grid geometry at the junctions of the sections was kept in mind. The fluid geometry was created using Ansys Geometry software. It was simplified, omitting all the outlines of the threaded connections that remained in the fluid area. In addition, the area around the injector plunger was limited to only the lower part, which had the greatest influence on the flow character. In order to measure selected hard-to-reach dimensions inside the injector, it was necessary to cut out the body walls, which was possible as several bodies were available. The pressure sensor itself, due to its design, only required the disassembly of the threaded connections to create the fluid geometry. The measurements required to create the fluid geometry used a tool with an accuracy of $0.05 \times 10^{-3} \mathrm{~m}$. In calculations it was necessary to leave the firing pin, which was used in experimental tests, in order to best represent the real working conditions of the injector. Of course, in the experimental tests, the analyzed sensor will work with a gas injector without the firing pin, where, of course, time until full opening and closing will be different due to a smaller mass in progressive motion. In order to maintain grid continuity, the injector plunger was offset from the seat by $0.05 \times 10^{-3} \mathrm{~m}$, which may cause a small leak, but due to the fast-variable process will not affect the calculation result.

In the initial phase of dividing the area into elements, a tetrahedral mesh was used (Figure $3 b, d$ ). In the different parts of the study area the maximum element size was taken as: moving wall (plunger) and side wall of the plunger $0.025 \times 10^{-3} \mathrm{~m}$; area under the plunger $0.05 \times 10^{-3} \mathrm{~m}$; and sensor plate $0.2 \times 10^{-3} \mathrm{~m}$. Two inflation layers and no slip were used on all walls. The global growth rate was set to 1.2. Other mesh parameters were selected systemically by Ansys software. Further using Fluent solving, the tetrahedral mesh was converted to a polyhedral mesh using system options including cell optimization (Figure $3 c, e)$. This was performed in order to reduce the computation time, which as reported in the literature [79-82], does not significantly affect the result. 


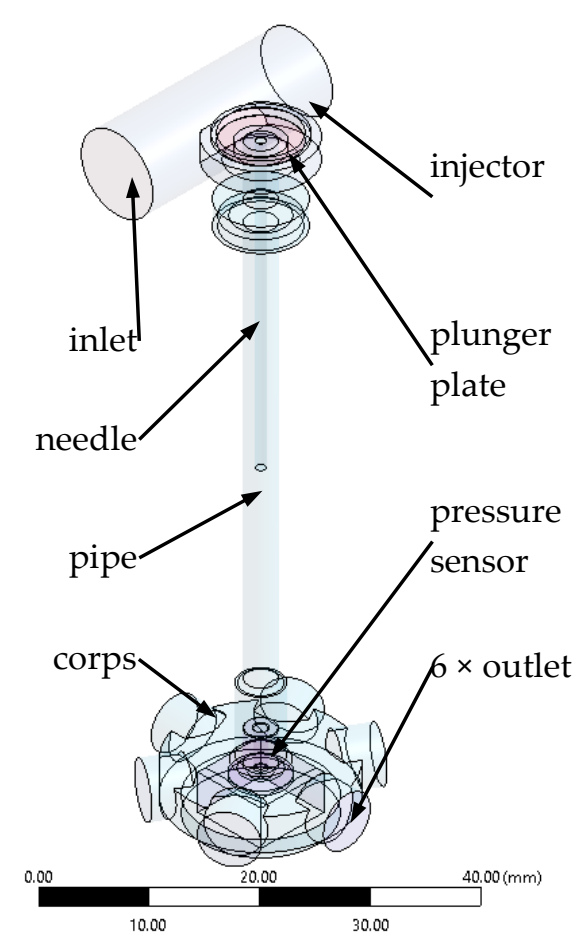

(a)

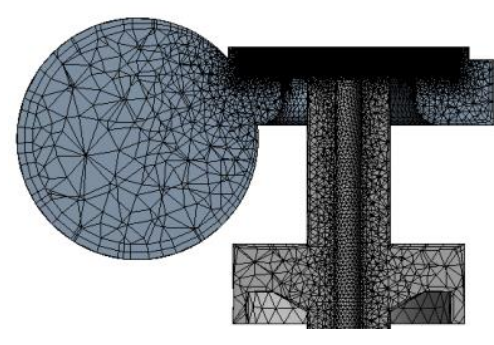

(b)

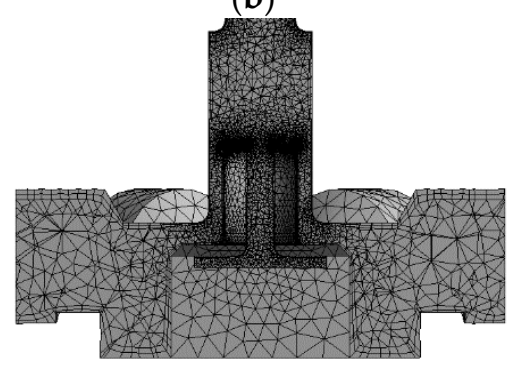

(d)

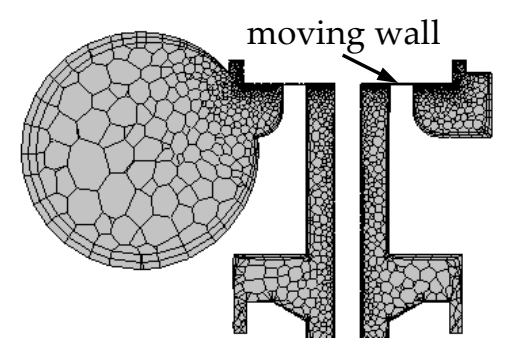

(c)

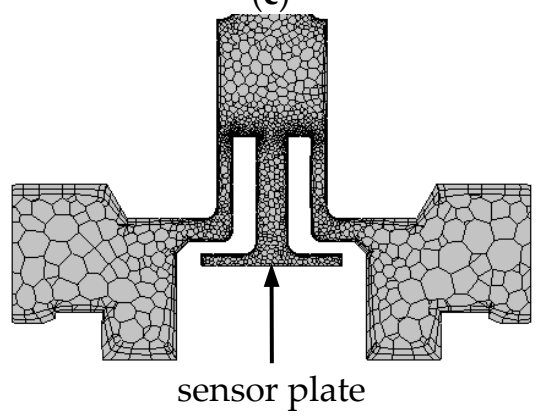

(e)

Figure 3. Steps in model conversion: (a)—solid model of the fluid; (b,d)—tetrahedral grid in the upper and lower parts of the study area; (c,e)-polyhedral grid in the upper and lower parts of the study area.

A standard SIMPLE scheme with control values of $1 \times 10^{-4}$ residuals was used to solve the flow problem in Ansys Fluent. The discretization of the continuity and momentum equations was carried out using a pressure-based solver. At steady state, the equations can be written in integral form (Equations (6) and (7)):

$$
\begin{gathered}
\rho \oint \vec{v} d \vec{A}=0 . \\
\rho \oint \vec{v} \vec{v} d \vec{A}=-\oint p \mathbf{I} d \vec{A}+\oint \bar{\tau} d \vec{A}+\int_{V} \vec{F} d V .
\end{gathered}
$$

where I is the identity matrix; $\bar{\tau}$ is the stress tensor; and $\vec{F}$ is the force vector.

Equation (7) is integrated by the control volume resulting in the discrete equation (Equation (8)):

$$
\sum_{f}^{N_{\text {faces }}} J_{f} A_{f}=0 .
$$

where $J_{f}$ is the mass flux through face $f, \rho v_{n}$.

In a further step, it was necessary to relate the velocity values $v_{n}$ to the surface. The averaging of velocity values over the face is realized by momentum-weighted averaging using the weighting factor $a_{p}$. We then write the frontal flux $J_{f}$ in the form of Equation (9):

$$
J_{f}=\rho \frac{a_{p, c_{0}} v_{n, c_{0}}+a_{p, c 1} v_{n, c_{1}}}{a_{p, c_{0}}+a_{p, c_{1}}}+d_{f}\left(\left(p_{c_{0}}+(\nabla p)_{c_{0}} \vec{r}_{0}\right)-\left(p_{c_{1}}+(\nabla p)_{c_{1}} \vec{r}_{1}\right)\right)=\hat{J}_{f}+d_{f}\left(p_{c_{0}}-p_{c_{1}}\right) .
$$

where $p_{c_{0}}$ and $p_{c 1}$ are the pressure within the two cells on either side of the face; $v_{h, c_{0}}$ and $v_{n, c_{1}}$ are the velocity within the two cells on either side of the face; $\hat{J}_{f}$ contains the influence of velocities in these cells; $d_{f}$ is a function; $\bar{a}_{p}$ the average of the momentum equation; and $a_{p}$ coefficients for the cells on either side of face $f$.

In the area of the moving wall, the parameters smoothing, layering, and remeshing were applied according to the requirements of the software used. Due to the length of 
the descriptions, they are not presented in the paper. The injectors plunge displacement required for flow studies was obtained from the experimental stand presented later in this paper.

Air was used as the working medium. In the experimental tests of the low-pressure gas-phase injector, it is used for safety reasons. The use of air was considered appropriate in the context of further reference to the experimental results of other gas injectors. Each time, the supply conditions, the inlet-outlet pressure differential, and the corresponding plunger displacement waveform were changed in the calculations.

\subsection{The Experimental Test Stand}

Validation of the numerical calculations was performed using a gas injector flow test stand. The tests were carried out using air as the working medium similarly to the calculations. The operation of the stand is as follows. Compressed air from the source of compressed air flowed through the air pressure stabilization system and further to the buffer tank Figure 4. The purpose of the buffer tank was to reduce pressure pulsations in the supply system during cyclic operation of the solenoid valve. From the buffer tank, air flowed to the inlet nozzle tested valve (Valtek Rail Type-30), and each time the valve was open, to the analyzed sensor. The cyclic operation of the solenoid valve was controlled by STAG AC LLC based pulse induction system controller with dedicated software. The analyzed sensor was powered with a car battery, while the measurement signal was supplied with a RIGOL MSO4014 oscilloscope. The pressure was recorded with a step of $0.01 \times 10^{-3} \mathrm{~s}$.

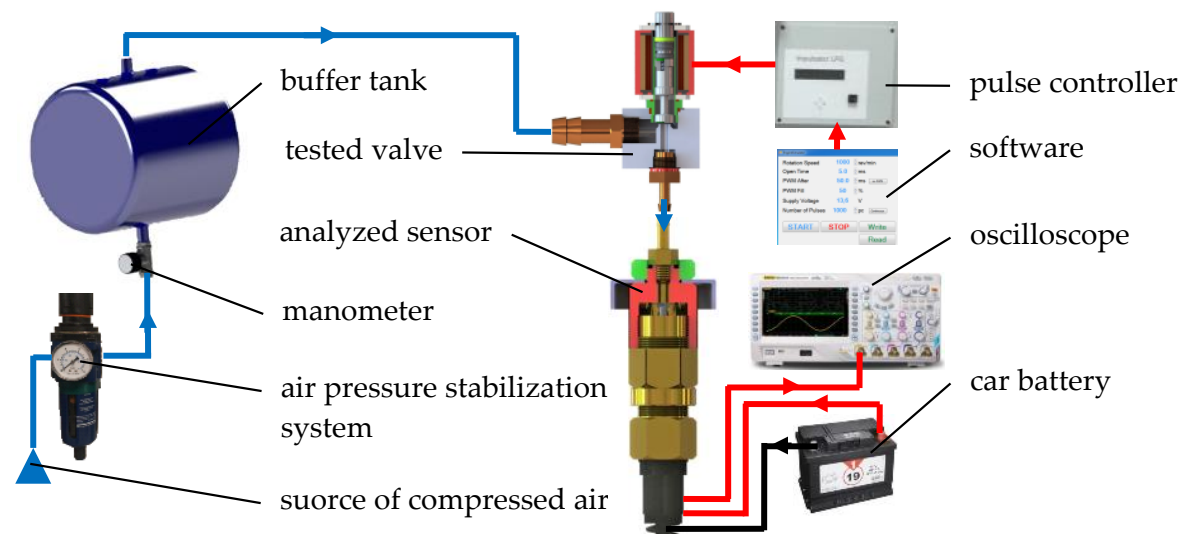

Figure 4. The scheme of the flow test stand.

In order to determine the course of the injector plunger stroke, the stand shown in Figure 4 was supplemented with additional equipment. The needle CL80 ZEPWM displacement sensor (response time: $<0.1 \times 10^{-3} \mathrm{~s}$, range: $\pm 1 \times 10^{-3} \mathrm{~m}$, accuracy: $1 \%$ ) was mounted on the plunger. The mass of the mounted needle was $0.64 \times 10^{-3} \mathrm{~kg}$, which increased the mass of the plunger by $11.26 \%$ (ABT-100 KERN scales). The static characteristics of the sensor was determined for which the coefficient of determination on the level of $R^{2}=99.97 \%$ was obtained. The RIGOL RP1500A (bandwidth $\sim 150 \times 10^{6} \mathrm{~Hz}$; damping factor-10:1) was used for the electric voltage measurement, while the HAMEG HZ050 (response time: $<0.1 \times 10^{-6}$ s, range: $\pm 30 \mathrm{~A}$, accuracy: $1 \%$ ) was used for the electric current measurement. Additionally, a KELAG KAS903-02A acceleration sensor (response time: $<1 \times 10^{-3} \mathrm{~s}$; repeatability $<4 \times 10^{-3} \mathrm{~g}$, range: $\pm 12 \mathrm{~g}$, accuracy: $0.005 \mathrm{~g}$ ) was mounted to the solenoid valve body. Acceleration sensor was to compare the functional parameters (time until full opening and closing) obtained with the displacement sensor. The signals were recorded with a RIGOL MSO4014 oscilloscope (bandwidth-100 $\times 10^{6} \mathrm{~Hz}$; real-time sample rate-up to $4 \times 10^{9} \mathrm{Sa} \cdot \mathrm{s}^{-1}$ ). The registration step was assumed to be $0.01 \times 10^{-3} \mathrm{~s}$.

In the initial stage, the effect of the mass of the firing pin mounted to the plunger on time of opening and closing the injector was evaluated. The tests were carried out 
at atmospheric pressure $p_{a}=1 \times 10^{5} \mathrm{~Pa}$, and ambient temperature $T_{a}=(20+273.15) \mathrm{K}$. The supply pressure was set at $p_{\text {in }}=1 \times 10^{5} \mathrm{~Pa}$, while the injection time (pulse time) at $5 \times 10^{-3} \mathrm{~s}$. Figure 5 shows the electric voltage and current, plunger displacement and acceleration of the electro valve corps. Time values read from Figure 5 were: total time until full opening $3.93 \times 10^{-3} \mathrm{~s}$ and total time until full closing $2.67 \times 10^{-3} \mathrm{~s}$, respectively. This increased time until full opening by about $15 \%$, and time until full closing by about $21 \%$, relative to the manufacturer's declaration (Table 2 ).

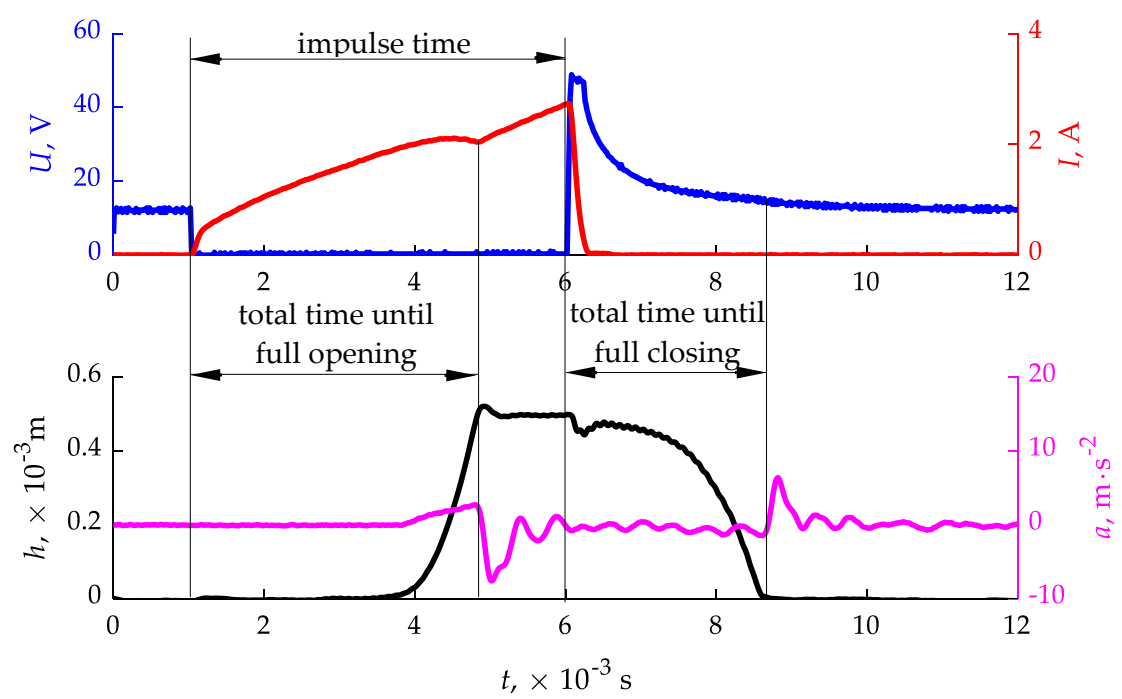

Figure 5. The measurements results: $U$-electric voltage (blue), I-electric current (red), $h$-plunger displacement (black), $a$-acceleration of the electro valve corps (magenta).

\section{Results and Discussion}

\subsection{Plunger Lift}

Before proceeding to the numerical analysis, it was necessary to determine the plunger lift as a function of time at a given pulse length controlling the opening of the solenoid valve. For this purpose, the flow stand presented in Figure 4 was used. The plunger lift courses were determined at various supply pressures $(0.25 \ldots 2.00) \times 10^{5} \mathrm{~Pa}$, step $0.25 \times 10^{5} \mathrm{~Pa}$ (Figure 6). Time characteristics of the plunger displacement were necessary to initiate the CFD.

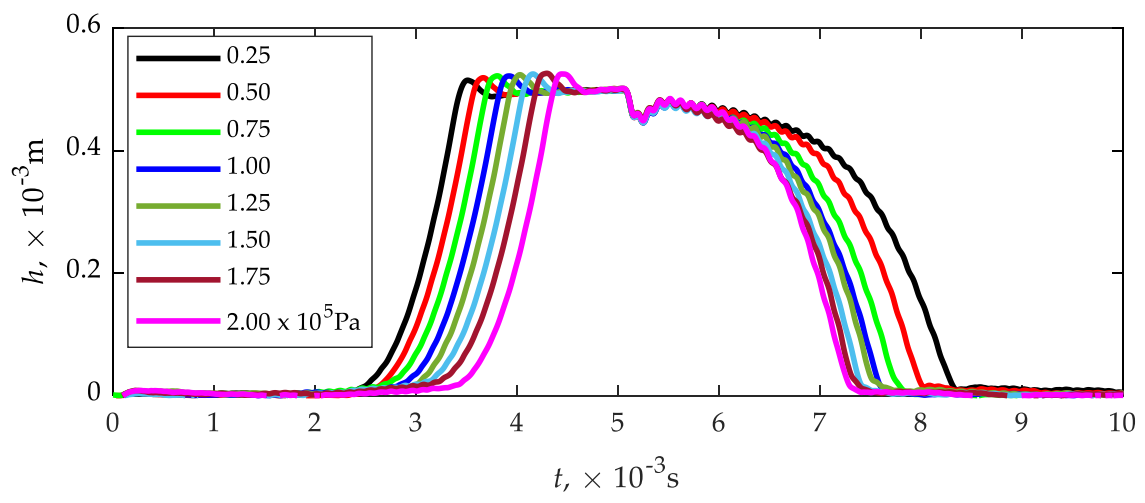

Figure 6. Plunger displacement curves depending on pressure supply $(0.25 \ldots 2.00) \times 10^{5} \mathrm{~Pa}$.

In order to reduce the CFD calculation time, the number of plunger displacement measurement points was limited to a time step of $0.1 \times 10^{-3} \mathrm{~s}$. Interpolation to the required time step was performed using the cubic spline method. The plunger waveform was loaded into the Ansys Fluent workspace taking into account the other required simulation conditions. 


\subsection{CFD Analysis}

In the initial phase of the CFD calculations, the influence of the mesh density on the pressure waveforms obtained at the pressure sensor measuring surface was checked (Figure 3e). For this purpose, four tests were carried out with the input grid parameters given in Table 3. The grid was initially constructed as a tetrahedral mesh, and in the first variant (mesh 1), the values proposed by the system were used. In further steps, the mesh was thickened (mesh 2...4). The input-output pressure difference was defined as a relative value of $1 \times 10^{5} \mathrm{~Pa}$ (output-ambient conditions). The calculation time step was defined as $1 \times 10^{-4} \mathrm{~s}$. The remaining calculation parameters were adopted in accordance with Section 2.3 of the study. In a further step, in order to reduce the calculation time, the tetrahedral mesh was converted into a polyhedral mesh using Fluent solving with the use of system options, including cell optimization.

Table 3. The grid parameters adopted in the initial part of the calculation.

\begin{tabular}{cccccccc}
\hline Variant & $\begin{array}{c}\text { Min Size, } \\
\text { mm }\end{array}$ & $\begin{array}{c}\text { Max Face } \\
\text { Size, mm }\end{array}$ & $\begin{array}{c}\text { Max Face } \\
\text { Size, mm }\end{array}$ & $\begin{array}{c}\text { Curvature Normal } \\
\text { Angle, deg }\end{array}$ & $\begin{array}{c}\text { Growth } \\
\text { Rate }\end{array}$ & $\begin{array}{c}\text { Elements } \\
\text { Skewness }\end{array} \begin{array}{c}\text { Orthogonal } \\
\text { Quality }\end{array}$ \\
\hline mesh $1^{*}$ & 0.01 & 1.22 & 2.45 & 18 & 1.2 & $2,353,288$ & 0.2264 \\
mesh 2 & 0.01 & 1.00 & 2.00 & 18 & 1.2 & $2,357,922$ & 0.2265 \\
mesh 3 & 0.01 & 0.25 & 0.50 & 18 & 1.2 & $3,282,392$ & 0.2249 \\
mesh 4 & 0.01 & 0.10 & 0.20 & 18 & 1.2 & $13,064,272$ & 0.2151 \\
\hline
\end{tabular}

* System proposal.

In all analyzed cases of mesh density (Table 3), the average quality parameters (skewness and orthogonal quality) should be considered correct [83]. For mesh 3 and mesh 4, the number of elements increased significantly which affected the calculation time. Based on the analysis of the influence of mesh density on the calculation results, it was concluded that the general mesh parameters proposed systemically (mesh 1 in Table 3), taking into account the local densities described in Section 2.3, are sufficient to identify time until full opening and closing of the gas injector (Figure 7). In the case of mesh 4 the calculations did not give a correct solution in the range $(5.5 \ldots 7.5) \times 10^{-3} \mathrm{~s}$, and the pressure waveform itself differed from the others. The task of the analyzed sensor is to identify times until full opening and closing of the gas injector. The opening pulse is in the range of $(0 \ldots 5) \times 10^{-3} \mathrm{~s}$, to which the plunger responds with opening $\mathrm{h}$ according to (Figure $7 \mathrm{a}$ ). While time until full closing at all tested mesh densities (Table 3 ) is easy to identify (pressure at the sensor drops to $0 \mathrm{~Pa}$ ), and is $2.8 \times 10^{-3} \mathrm{~s}$, the identification of time until full opening becomes a problem. In this case, it is proposed to evaluate time until full opening on the basis of the "inflection" point of the pressure course (Figure 7b). A sharp increase in pressure on the sensor plate corresponds to time until full opening of the injector. On the other hand, a decrease in the incremental gradient signals full opening. All tested mesh (mesh $1 \ldots$ 4) density variants gave the possibility of identifying times until full opening; therefore, mesh 1 was selected for further analyses, as in this case the calculations were the least time-consuming. Note that the identification of injector times until full opening and closing is derived from time step $\left(1 \times 10^{-4} \mathrm{~s}\right)$ and can be reported with this accuracy.

The value of the inlet-outlet pressure equation in the range $(0.25 \ldots 2.00) \times 10^{5} \mathrm{~Pa}$ was assumed as a variable in the calculation. The pressure differential was adjusted by leaving ambient conditions at the outlet. This was dictated by the fact that a pressure sensor was used to evaluate the functional parameters of the injector and its sensitivity to this variable is important. In tests of the low-pressure gas-phase injectors, the pressure difference is usually $1 \times 10^{5} \mathrm{~Pa}$, but it was considered important to know a specific range around this value. The obtained waveforms/values may be applicable in modelling transient processes of the engine power system operation, where the pressure difference may be different than $1 \times 10^{5} \mathrm{~Pa}$. For the calculations to be correct, it was necessary to determine the experimental plunger lift curves at different inlet-outlet pressures, since they affect the injector times until full opening and closing, as described in [84]. By taking the plunger lift 
curves (Figure 6) and varying the pressure in the range $(0.25 \ldots 2.00) \times 10^{5} \mathrm{~Pa}$, the sensor plate pressure variation curves (Figure 8 ) were obtained.

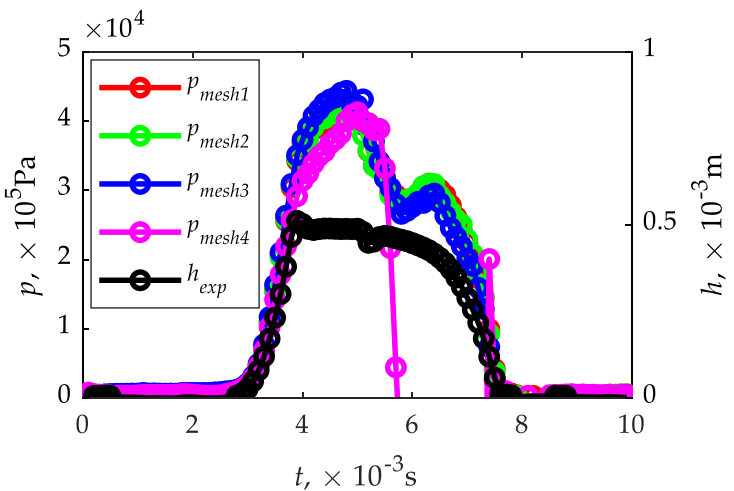

(a)

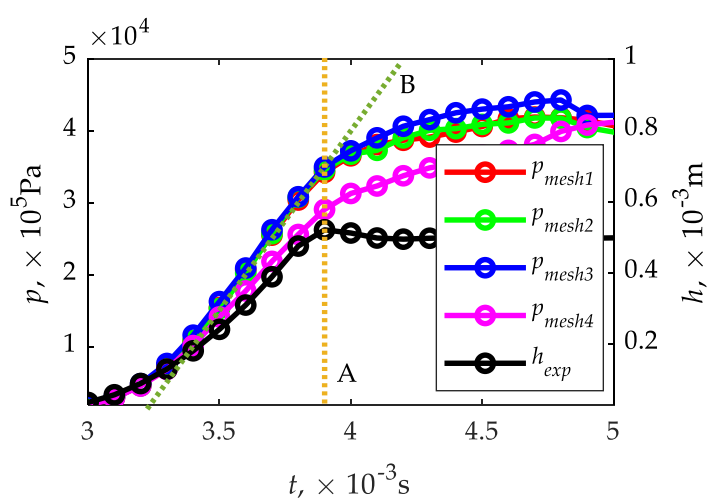

(b)

Figure 7. Identification of injector times until full opening and closing from pressure waveforms on the sensor plate: (a) —whole waveforms; (b)—selected range of waveforms.

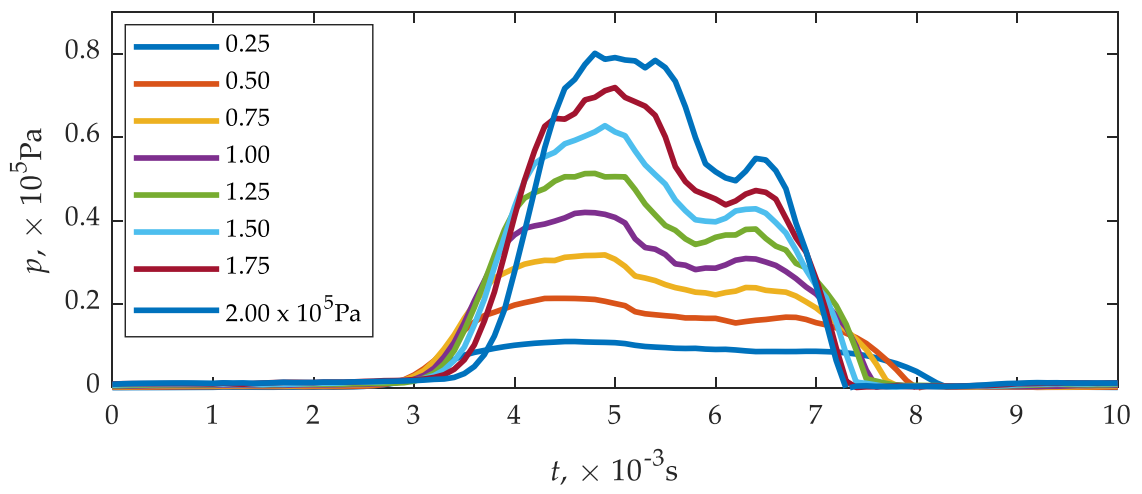

Figure 8. Pressure waveforms on the sensor plate of the analyzed sensor.

The effect of pressure on times until full opening and closing can be seen (Figure 8), for which the plunger lift curve is directly responsible. An increase in pressure causes an increase in time until full opening, which is due to the need to overcome more pressure on the plunger. The pressure has the opposite effect on time until full closing, time decreases.

Figure 9 shows the pressure distributions of selected zones of the tested system, near the plunger and the pressure sensor (pressure difference $1 \times 10^{5} \mathrm{~Pa}$ ). In the initial phase $\left(t=2 \times 10^{-3} \mathrm{~s}\right)$, the pressure difference caused by the initial simulation conditions is visible, while the maximum pressure occurs in the injector area. The need to maintain the continuity of the grid resulting in a gap between the plunger plate and the seat of $0.05 \times 10^{-3} \mathrm{~m}$ does not substantially affect the pressure distribution in the zone behind the plunger plate (Figure 9a,d). At the maximum opening of the injector $\left(t=5 \times 10^{-3} \mathrm{~s}\right)$, the flow of air from the injector to the duct and further to the pressure sensor causes an increase in pressure at the sensor plate (Figure $9 \mathrm{~b}, \mathrm{e})$. When the injector is closed $\left(t=7.5 \times 10^{-3} \mathrm{~s}\right.$ ), there is negative pressure in the area under the plunger plate, but this is not reflected in the sensor plate (Figure 9c,f). 


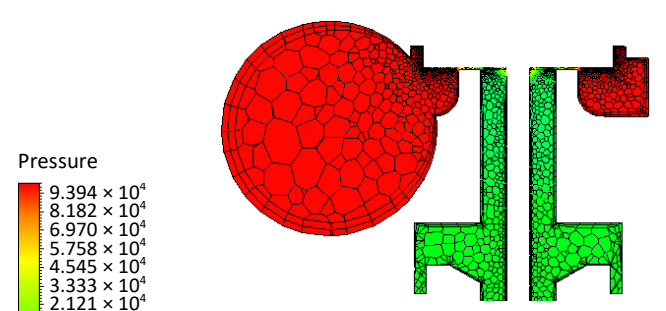

(a)

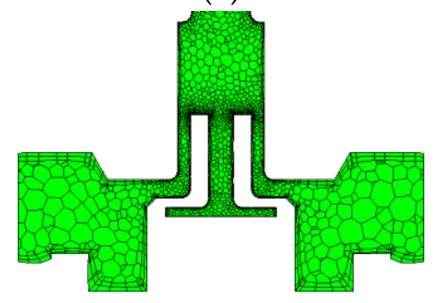

(d)

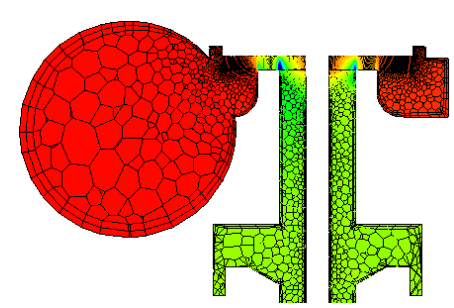

(b)

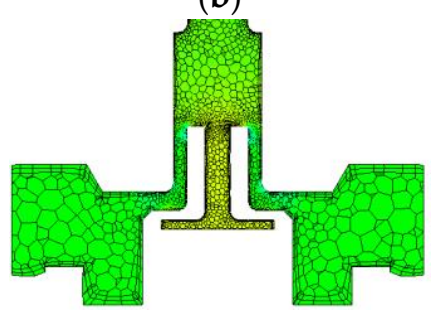

(e)

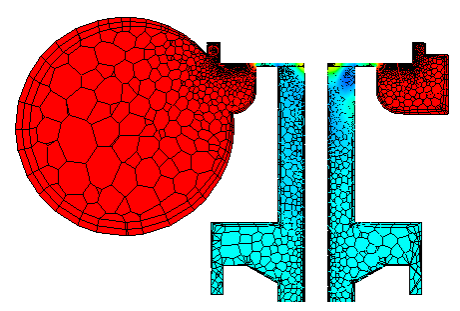

(c)

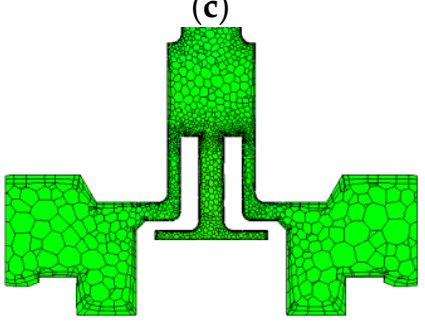

(f)

Figure 9. Pressure distributions around the plunger and pressure sensor: $(\mathbf{a}, \mathbf{d})-t=2 \times 10^{-3} \mathrm{~s} ;(\mathbf{b}, \mathbf{e})-t=4 \times 10^{-3} \mathrm{~s}$; $(\mathbf{c}, \mathbf{f})-t=7.5 \times 10^{-3} \mathrm{~s}$.

\subsection{Validation of the CFD Calculation Results}

In the final stage of the analysis, the results of the CFD calculations were validated. For this purpose, the analyzed sensor was mounted on the test stand presented in Section 2.4. By varying the inlet pressure in the range of $(0.25 \ldots 2.00) \times 10^{5} \mathrm{~Pa}$ at a fixed outlet pressure (ambient conditions), experimental tests were carried out, which were compared with the waveforms calculated using CFD (Figure 10). The identification of times until full opening and closing was referred to the plunger lift determined in the earlier study. The increasing difference in the maximum values of pressure obtained from the CFD calculations and those obtained from the experimental tests of the analyzed sensor may result from the simplification that was made by creating a solid model of the fluid. It was assumed in the calculations that the output pressure would be the averaged pressure with the sensor plate at the rigid wall (Figure 3). In the measurement system of the actual sensor, there is a diaphragm that acts on the piezoelectric sensor. Due to the deformation of the diaphragm, it acts with a certain delay when the pressure rises, as can be seen in the experimental runs (Figure 10). The higher the pressure, which flows from the injector to the sensor, the faster the diaphragm deformation and, as a result, the impact, which can be seen in the form of a peak. On the other hand, when the pressure drops, in addition to the deformation of the diaphragm, it is necessary to remove air from the measuring chamber, which can be the reason for the delay in operation when evaluating the time until full closing. In the comparative analysis of CFD calculations and experimental tests, it should also be borne in mind that the tests are of a fast-variable character, and the response time declared by the sensor manufacturer at the maximum level of $1 \times 10^{-3} \mathrm{~s}$ may appear both at the increase and decrease in pressure. Apart from looking for the reasons of discrepancies between the results of CDF calculations and experimental investigations on the side of sensor operation and replacement of the diaphragm with a rigid reference wall, one should also take into account the imperfection of the mathematical model as well as simplifications in the solid model of the fluid. The k- $\omega$ SST model used in this study, which combines features of the $k-\varepsilon$ and $k-\omega$ models, may not sufficiently represent the nature of the flow. The flow in the area of gas injector-pressure sensor is characterized by high complexity due to differentiation of flow cross-section and fast variability of the process. The dynamic rebuilding of the mesh created when the injector is opened may also be here for a reason. However, the most likely cause of the differences is the susceptible diaphragm in the sensor measurement system, which essentially delays the identification of the closing process due to the need to remove air. 


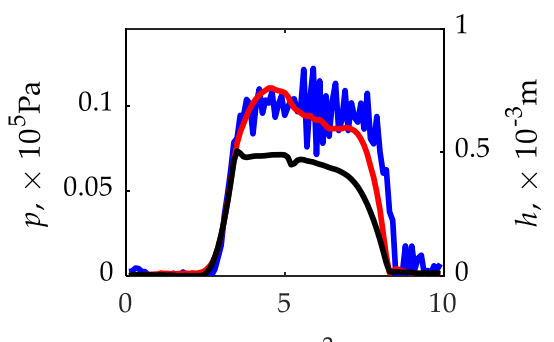

t, $\times 10^{-3} \mathrm{~s}$

(a)

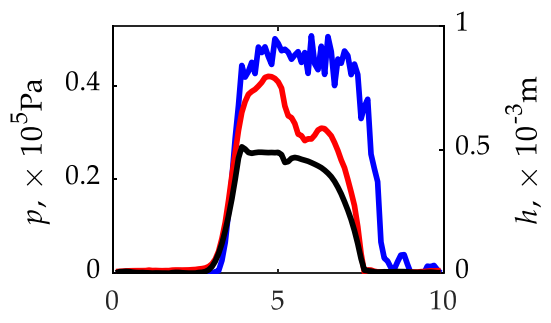

$t, \times 10^{-3} \mathrm{~s}$

(d)

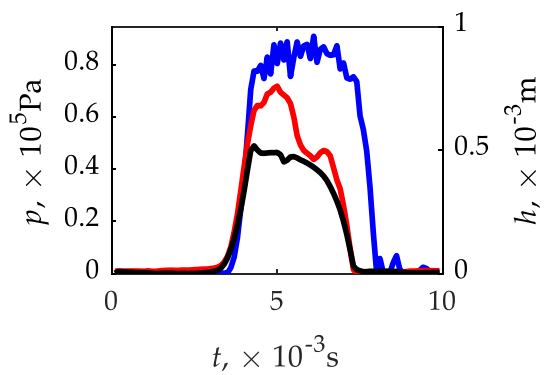

(g)

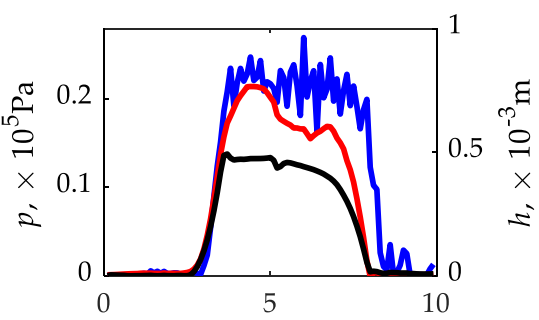

t, $\times 10^{-3} \mathrm{~s}$

(b)

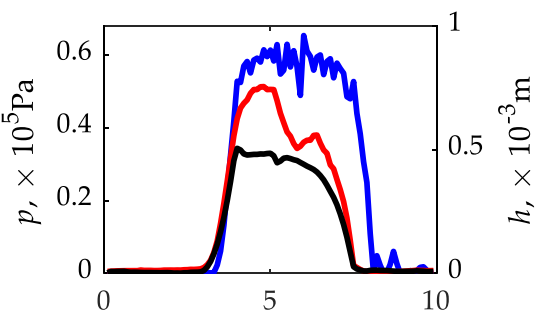

$t, \times 10^{-3} \mathrm{~s}$

(e)

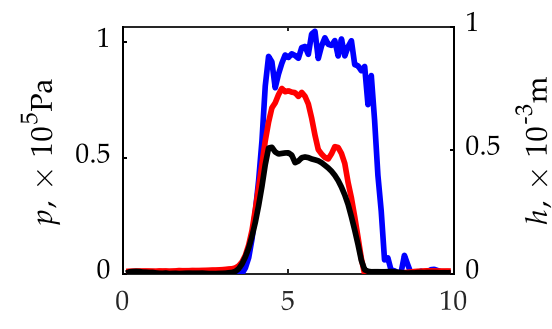

t, $\times 10^{-3} \mathrm{~s}$

(h)

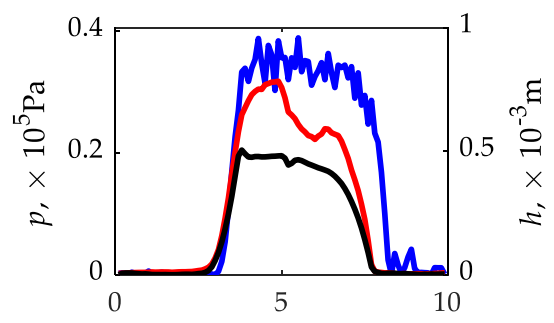

$t, \times 10^{-3} \mathrm{~s}$

(c)

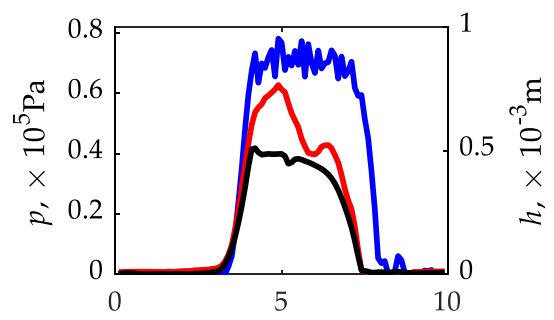

$t, \times 10^{-3} \mathrm{~s}$

(f)

Figure 10. Validation of the CFD calculation results. Legend: (a) $-0.25 \times 10^{5} \mathrm{~Pa}$; (b) $-0.25 \times 10^{5} \mathrm{~Pa}$; (c) $-0.25 \times 10^{5} \mathrm{~Pa}$; (d) $-0.25 \times 10^{5} \mathrm{~Pa}$; (e) $-0.25 \times 10^{5} \mathrm{~Pa}$; (f) $-0.25 \times 10^{5} \mathrm{~Pa}$; (g) $-0.25 \times 10^{5} \mathrm{~Pa}$; (h) $-0.25 \times 10^{5} \mathrm{~Pa}$; displacement sensor (black); - pressure from CFD calculation (red); - experimentally determined pressure (blue).

It can be seen (Figure 10) that there is agreement in times until full opening and closing comparing CFD calculations and plunder displacement. As for times until full opening in relation CFD calculations-experimental tests of the sensor, they agree for $(0.75 ; 1.00 ; 1.25$, and 1.75$) \times 10^{5} \mathrm{~Pa}$, in other cases $(0.25 ; 0.50 ; 1.50$, and 2.00$) \times 10^{5} \mathrm{~Pa}$ the differences do not exceed 3\% (Tables 4 and 5). On the other hand, the times until full closing determined from CFD calculations and the displacement sensor are in agreement (Tables 4 and 5). The situation is slightly worse in the relation between CFD calculations and experimental tests of the analyzed sensor. In this case, CFD calculations are characterized by significant discrepancies. Only for the differential pressure of $0.25 \times 10^{5} \mathrm{~Pa}$ the relative error is below $10 \%$, for the rest it reaches $21 \%$ (Table 5 ).

Table 4. Times until full opening and closing of the gas injector identified using different methods.

\begin{tabular}{cccccccccc}
\hline \multirow{2}{*}{ Method } & \multirow{2}{*}{ Time, $\times \mathbf{1 0}^{\mathbf{- 3}} \mathbf{s}$} & \multicolumn{7}{c}{$p_{\boldsymbol{s}} \times \mathbf{1 0}^{\mathbf{5}} \mathbf{P a}$} \\
\cline { 3 - 9 } & & 0.25 & 0.50 & 0.75 & 1.00 & 1.25 & 1.50 & 1.75 & 2.00 \\
\hline \multirow{2}{*}{$\begin{array}{c}\text { displacement } \\
\text { sensor }\end{array}$} & $t_{t f o}$ & 3.50 & 3.70 & 3.80 & 3.90 & 4.00 & 4.20 & 4.20 & 4.40 \\
\hline CFD & $t_{t f c}$ & 3.30 & 3.00 & 3.00 & 2.80 & 2.60 & 2.40 & 2.40 & 2.40 \\
simulation & $t_{t f o}$ & 3.50 & 3.70 & 3.80 & 3.90 & 4.00 & 4.20 & 4.20 & 4.40 \\
\hline \multirow{2}{*}{ experimentally } & $t_{t f c}$ & 3.30 & 3.00 & 3.00 & 2.80 & 2.60 & 2.40 & 2.40 & 2.40 \\
& $t_{t f f o}$ & 3.40 & 3.60 & 3.80 & 3.90 & 4.00 & 4.10 & 4.20 & 4.50 \\
& $t_{t f c}$ & 3.50 & 3.50 & 3.50 & 3.30 & 3.10 & 2.90 & 2.90 & 2.90 \\
\hline
\end{tabular}


Table 5. Relative difference in the injector times until full opening and closing determined with respect to the displacement sensor.

\begin{tabular}{|c|c|c|c|c|c|c|c|c|c|}
\hline \multirow{2}{*}{ Method } & \multirow{2}{*}{$\begin{array}{c}\text { Relative } \\
\text { Difference, \% }\end{array}$} & \multicolumn{8}{|c|}{$p_{s} \times 10^{5} \mathrm{~Pa}$} \\
\hline & & 0.25 & 0.50 & 0.75 & 1.00 & 1.25 & 1.50 & 1.75 & 2.00 \\
\hline \multirow{2}{*}{$\begin{array}{l}\text { CFD simu- } \\
\text { lation }\end{array}$} & $\Delta t_{t f_{0}}$ & 0.00 & 0.00 & 0.00 & 0.00 & 0.00 & 0.00 & 0.00 & 0.00 \\
\hline & $\Delta t_{t f c}$ & 0.00 & 0.00 & 0.00 & 0.00 & 0.00 & 0.00 & 0.00 & 0.00 \\
\hline \multirow{2}{*}{ experimentally } & $\Delta t_{t f_{o}}$ & -2.86 & -2.70 & 0.00 & 0.00 & 0.00 & -2.38 & 0.00 & 2.27 \\
\hline & $\Delta t_{t f_{c}}$ & 6.06 & 16.67 & 16.67 & 17.86 & 19.23 & 20.83 & 20.83 & 20.83 \\
\hline
\end{tabular}

On the basis of the obtained results of CFD calculations and experimental tests, the influence of the inlet-outlet pressure difference on the times until full opening and closing of the gas injector Figure 11 was confirmed, which was signaled for a different injector design solution in [84]. Apart from an inlet-outlet pressure difference of $0.25 \times 10^{5} \mathrm{~Pa}$, the times until full closing determined experimentally differ significantly from those obtained from CFD calculations (Figure 11).

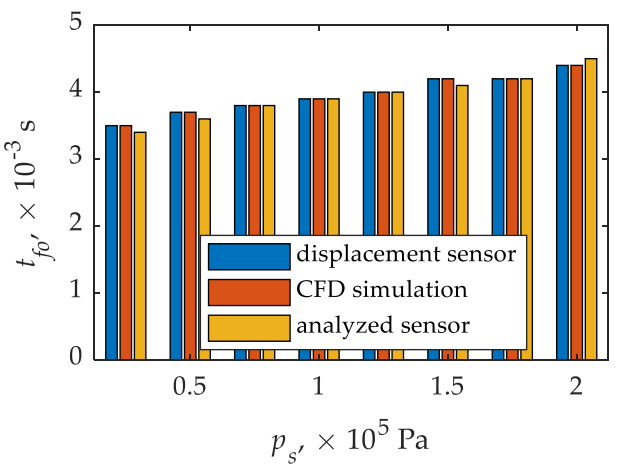

(a)

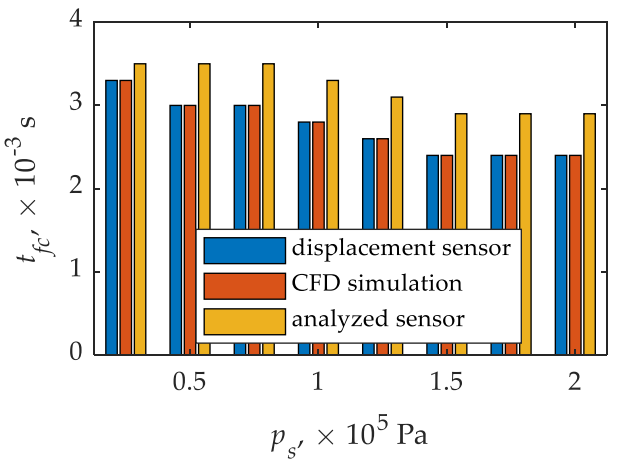

(b)

Figure 11. Influence of inlet-outlet pressure difference on injector times until full opening and closing. Legend: (a)-until full opening; (b)-until full closing.

The relative differences in the identified times until full opening and closing of the gas injector, presented in Figure 12, can be attributed to simplifications in the creation of the solid model of the fluid, indicated earlier in the paper, which do not fully reflect the measurement capabilities of the actual sensor.

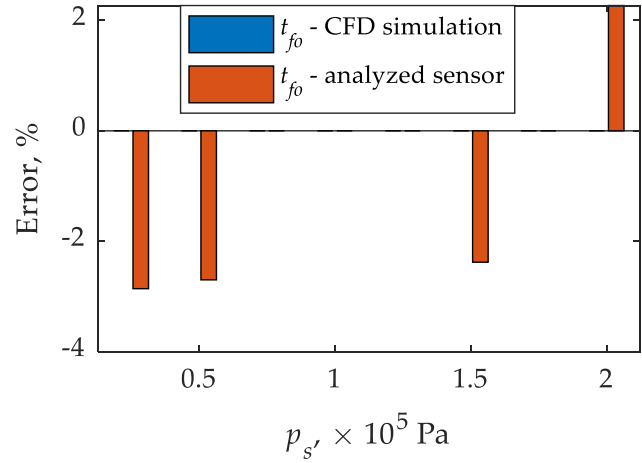

(a)

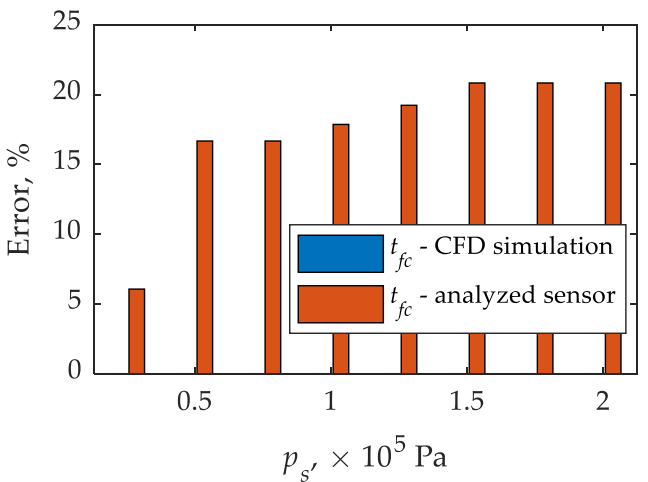

(b)

Figure 12. Relative differences in times until full opening and closing obtained from CFD calculations and experimentally. Legend: (a)-until full opening; (b)-until full closing. 


\section{Conclusions}

The aim of the study was a CFD flow analysis of an original pressure sensor used to determine times until full opening and closing of the low-pressure gaseous phase solenoid valve. Despite the ever-increasing share of direct injection engines, alternative power systems using indirect LPG injection are among the most popular in transport. The evaluation of a fast-changing process such as gas injection can be performed by many methods. In the study, an original pressure sensor was proposed, with the use of which the evaluation times until full opening and closing is possible. The evaluation of these times uses the pressure waveforms and their interpretation. In the initial stage, a simplified solid model of the fluid was created and then a finite element mesh was applied. Using the dynamic mesh generation capabilities of Ansys Fluent software, calculations were carried out to determine the pressure waveform on the sensor plate during the opening and closing of the gas injector. The plunger displacement waveforms required for the calculations were determined experimentally. In the final stage, the CFD results were validated using the real object and the original test bench.

On the basis of the conducted research, it has been stated:

- The proposed simplified solid fluid model allowed to reflect the flow capabilities of the investigated gas injector-pressure sensor system.

- The analyzed mesh densities in a global view together with local user definitions showed differences in the runs. In all mesh cases, the mean quality parameters, skewness (0.22), and orthogonal quality (0.86) were of good quality. Each of the presented mesh densities gave the possibility to identify the times until full opening and closing of the injector, so it was decided to use the system-proposed mesh with local user definitions. Due to time-consuming calculations, the final models used a polyhedral mesh built systemically with cell optimization.

- Experimental studies using a plunger displacement sensor showed a $15 \%$ increase in time until full opening and $21 \%$ increase in time until full closing. This was due to the use of a needle in the injector operating system. The results were necessary to initiate a dynamic mesh in Ansys Fluent. The needle was left in CFD calculations and validation on the experimental bench.

- The indirect method of evaluating times until full opening based on the pressure waveform on the pressure sensor plate had a positive effect. The drop in the pressure rise gradient coincided with the maximum lift determined using the plunger displacement sensor.

- The indirect method of evaluating times until full injector closing, when pressure at the pressure sensor plate drops to $0 \mathrm{~Pa}$, is also able to represent the end of the injector closing process.

- The times until full opening of the injector determined using plunger displacement sensor, CFD simulation, and pressure plate sensor give similar results. No differences were found at inlet-outlet pressure differences $(0.75 ; 1.00 ; 1.25$, and 1.75$) \times 10^{5} \mathrm{~Pa}$ by relating the pressure waveforms to the displacement sensor. In the remaining cases $(0.25,0.50,1.50$, and 2.00$) \times 10^{5} \mathrm{~Pa}$, the differences did not exceed $3 \%$;

- In the case of times until full closing of the injector in the relation CFD calculationsexperimental studies, only for the pressure difference of $0.25 \times 10^{5} \mathrm{~Pa}$ the relative error is below $10 \%$, in the remaining cases it reached $21 \%$. The simplification of the solid model of the fluid on the one hand, and the reaction time of the real object on the other, may be responsible for such a significant difference;

The performed tests confirmed the functional correctness of the analyzed pressure sensor. Possible reasons for differences in the determined times of until full opening and closing of the injector were explained. At a later stage, we plan to make an original connection, which will bring the pressure sensor as close as possible to the injector valve, which should positively influence the evaluation of the times in question. 
Author Contributions: D.S. supervised all analyses, conceived the article, participated in most of the research and wrote the paper; G.M. and A.B. performed the experimental studies; V.L. performed the CFD analyses; S.D. and T.P. reviewed and edited, visualization, validation, and formal analysis. All authors have read and agreed to the published version of the manuscript.

Funding: This publication was financed through the program of the Ministry of Science and Higher Education of Poland named "Regional Initiative of Excellence" in 2019-2022 project number 011/RID/2018/19.

Institutional Review Board Statement: Not applicable.

Informed Consent Statement: Not applicable.

Data Availability Statement: Data sharing not applicable.

Acknowledgments: This research was founded through subsidy of the Ministry of Science and Higher Education of Poland for the discipline of mechanical engineering at the Faculty of Mechanical Engineering Bialystok University of Technology WZ/WM-IIM/4/2020.

Conflicts of Interest: The authors declare no conflict of interest.

\section{References}

1. Raslavičius, L.; Keršys, A.; Makaras, R. Management of hybrid powertrain dynamics and energy consumption for 2WD, 4WD, and HMMWV vehicles. Renew. Sustain. Energy Rev. 2017, 68, 380-396. [CrossRef]

2. Brejaud, P.; Higelin, P.; Charlet, A.; Colin, G.; Chamaillard, Y. Échange de chaleur convectif dans un moteur hybride pneumatique. Oil Gas Sci. Technol. 2011, 66, 1035-1051. [CrossRef]

3. Raslavičius, L.; Azzopardi, B.; Keršys, A.; Starevičius, M.; Bazaras, Ž.; Makaras, R. Electric vehicles challenges and opportunities: Lithuanian review. Renew. Sustain. Energy Rev. 2015, 42, 786-800. [CrossRef]

4. Fang, Y.; Lu, Y.; Yu, X.; Roskilly, A.P. Experimental study of a pneumatic engine with heat supply to improve the overall performance. Appl. Therm. Eng. 2018, 134, 78-85. [CrossRef]

5. Korbut, M.; Szpica, D. A Review of Compressed Air Engine in The Vehicle Propulsion System. Acta Mech. Autom. 2021, 15, 215-226. [CrossRef]

6. Dimitrova, Z.; Maréchal, F. Gasoline hybrid pneumatic engine for efficient vehicle powertrain hybridization. Appl. Energy 2015, 151, 168-177. [CrossRef]

7. Myung, C.-L.; Lee, H.; Choi, K.; Lee, Y.J.; Park, S. Effects of gasoline, diesel, LPG, and low-carbon fuels and various certification modes on nanoparticle emission characteristics in light-duty vehicles. Int. J. Automot. Technol. 2009, 10, 537-544. [CrossRef]

8. Jemni, M.A.; Kassem, S.H.; Driss, Z.; Abid, M.S. Effects of hydrogen enrichment and injection location on in-cylinder flow characteristics, performance and emissions of gaseous LPG engine. Energy 2018, 150, 92-108. [CrossRef]

9. Bielaczyc, P.; Woodburn, J. Trends in Automotive Emission Legislation: Impact on LD Engine Development, Fuels, Lubricants and Test Methods: A Global View, with a Focus on WLTP and RDE Regulations. Emiss. Control Sci. Technol. 2019, 5, 86-98. [CrossRef]

10. Clairotte, M.; Suarez-Bertoa, R.; Zardini, A.A.; Giechaskiel, B.; Pavlovic, J.; Valverde, V.; Ciuffo, B.; Astorga, C. Exhaust emission factors of greenhouse gases (GHGs) from European road vehicles. Environ. Sci. Eur. 2020, 32, 125. [CrossRef]

11. Jeuland, N.; Montagne, X.; Duret, P. New HCCI/CAI combustion process development: Methodology for determination of relevant fuel parameters. Oil Gas Sci. Technol. 2004, 59, 571-579. [CrossRef]

12. Haraldsson, G. Closed-Loop Combustion Control of a Multi Cylinder HCCI Engine using Variable Compression Ratio and Fast Thermal Management; Division of Combustion Engines, Lund Institute of Technology: Lund, Sweden, 2005.

13. Mikulski, M.; Balakrishnan, P.R.; Doosje, E.; Bekdemir, C. Variable Valve Actuation Strategies for Better Efficiency Load Range and Thermal Management in an RCCI Engine. SAE Tech. Pap. 2018, 1, 254.

14. Pielecha, I.; Sidorowicz, M. Effects of mixture formation strategies on combustion in dual-fuel engines-A review. Combust. Engines 2021, 184, 30-40. [CrossRef]

15. Ziegler, M. The Road to Euro 7. MTZ Worldw. 2020, 81, 14-15. [CrossRef]

16. Ball, D.; Meng, X.; Weiwei, G. Vehicle Emission Solutions for China 6b and Euro 7. SAE Tech. Pap. 2020, 1, 654.

17. Council of the European Union. Council Directive 2014/94/EU of 22 October 2014 on the Deployment of Alternative Fuels Infrastructure; Council of the European Union: Strasbourg, France, 2014.

18. Mitukiewicz, G.; Dychto, R.; Leyko, J. Relationship between LPG fuel and gasoline injection duration for gasoline direct injection engines. Fuel 2015, 153, 526-534. [CrossRef]

19. Dziewiatkowski, M.; Szpica, D.; Borawski, A. Evaluation of impact of combustion engine controller adaptation process on level of exhaust gas emissions in gasoline and compressed natural gas supply process. In Proceedings of the Engineering for Rural Development; 2020; Volume 19, pp. 541-548, ERD 2020, Jelgava.

20. Warguła, Ł.; Kukla, M.; Lijewski, P.; Dobrzyński, M.; Markiewicz, F. Influence of the use of Liquefied Petroleum Gas (LPG) systems in woodchippers powered by small engines on exhaust emissions and operating costs. Energies 2020, 13, 5773. [CrossRef] 
21. Warguła, Ł.; Kukla, M.; Lijewski, P.; Dobrzyński, M.; Markiewicz, F. Impact of Compressed Natural Gas (CNG) fuel systems in small engine wood chippers on exhaust emissions and fuel consumption. Energies 2020, 13, 6709.

22. Jin, J.; Feng, M. Research and development of marine LPG engines. In Proceedings of the Energy and the EnvironmentProceedings of the International Conference on Energy and the Environment; 2003; Volume 1.

23. Machacon, H.T.C.; Yamagata, T.; Sekita, H.; Uchiyama, K.; Shiga, S.; Karasawa, T.; Nakamura, H. CNG operation of a two-stroke, two-cylinder marine S.I. Engine and its characteristics of self-ignition combustion. JSAE Rev. 2000, 21, 1-10. [CrossRef]

24. Wendeker, M.; Jakliński, P.; Czarnigowski, J.; Boulet, P.; Breaban, F. Operational parameters of LPG fueled si engine-Comparison of simultaneous and sequential port injection. SAE Tech. Pap. 2007, 2007-01-2051.

25. Raslavičius, L.; Keršys, A.; Mockus, S.; Keršiene, N.; Starevičius, M. Liquefied petroleum gas (LPG) as a medium-term option in the transition to sustainable fuels and transport. Renew. Sustain. Energy Rev. 2014, 32, 513-525. [CrossRef]

26. Korzeniewski, M. Development of a hybrid gas and electrical installation for direct-injected engine vehicles. Prz. Elektrotechniczny 2020, 97, 121-124. [CrossRef]

27. Czarnigowski, J. Teoretyczno-Empiryczne Studium Modelowania Impulsowego Wtryskiwacza Gazu; Wydawnictwo Politechniki Lubelskiej: Lublin, Poland, 2012.

28. Szpica, D. The influence of selected adjustment parameters on the operation of LPG vapor phase pulse injectors. J. Nat. Gas Sci. Eng. 2016, 34, 1127-1136. [CrossRef]

29. Szpica, D.; Czaban, J. Operational assessment of selected gasoline and LPG vapour injector dosage regularity. Mechanika 2014, 20, 480-488. [CrossRef]

30. Majerczyk, A.; Radzimirski, S. Effect of LPG gas fuel injectors on the properties of flow emission vehicles. J. KONES Powertrain Transp. 2012, 19, 401-410. [CrossRef]

31. Sim, H.; Lee, K.; Chung, N.; Sunwoo, M. A study on the injection characteristics of a liquid-phase liquefied petroleum gas injector for air-fuel ratio control. Proc. Inst. Mech. Eng. Part D J. Automob. Eng. 2005, 219, 1037-1046. [CrossRef]

32. Myung, C.-L.; Ko, A.; Lim, Y.; Kim, S.; Lee, J.; Choi, K.; Park, S. Mobile source air toxic emissions from direct injection spark ignition gasoline and LPG passenger car under various in-use vehicle driving modes in Korea. Fuel Process. Technol. 2014, 119, 19-31. [CrossRef]

33. Masi, M. Experimental analysis on a spark ignition petrol engine fuelled with LPG (liquefied petroleum gas). Energy 2012, 41, 252-260. [CrossRef]

34. Szpica, D. New Leiderman-Khlystov Coefficients for Estimating Engine Full Load Characteristics and Performance. Chinese J. Mech. Eng. 2019, 32. [CrossRef]

35. Duk, M.; Czarnigowski, J. The method for indirect identification gas injector opening delay time. Prz. Elektrotechniczny 2012, 88, 59-63.

36. Szpica, D. Validation of indirect methods used in the operational assessment of LPG vapor phase pulse injectors. Meas. J. Int. Meas. Confed. 2018, 118, 253-261. [CrossRef]

37. Więcławski, K.; Mączak, J.; Szczurowski, K. Electric current waveform of the injector as a source of diagnostic information. Sensors 2020, 20, 4151. [CrossRef]

38. Czarnigowski, J. The impact of supply pressure on gas injector expenditure characteristics. Silniki Spalinowe 2010, 49, 18-26. [CrossRef]

39. Szpica, D. The determination of the flow characteristics of a low-pressure vapor-phase injector with a dynamic method. Flow Meas. Instrum. 2018, 62, 44-55. [CrossRef]

40. Szpica, D. Investigating fuel dosage non-repeatability of low-pressure gas-phase injectors. Flow Meas. Instrum. 2018, 59, 147-156. [CrossRef]

41. Ambrozik, A.; Kurczyński, D. Analysis of fast-changing quantities in the AD3.152 UR engine running of mineral fuel, plant fuel and their blends. Motrol 2008, 10, 11-22.

42. Borawski, A. Simulation studies of LPG injector used in 4th generation installations. Combust. Engines 2015, 160, 49-55. [CrossRef]

43. Dongiovanni, C.; Dongiovanni, C.; Coppo, M. Accurate Modelling of an Injector for Common Rail Systems. In Fuel Injection; Daniela, S., Ed.; IntechOpen: London, UK, 2010.

44. Amirante, R.; Coratella, C.; Distaso, E.; Rossini, G.; Tamburrano, P. Optical device for measuring the injectors opening in common rail systems. Int. J. Automot. Technol. 2017, 18, 729-742. [CrossRef]

45. Wang, J.; Zhang, Y.; Yuan, X.Y. Noncontact measurement of needle displacement in electronic controlled fuel injector. In Proceedings of the 2010 International Conference on Measuring Technology and Mechatronics Automation, ICMTMA 2010, Changsha, China, 13-14 March 2010; Volume 2, pp. 777-780.

46. AC STAG Autogas Section. Available online: https://www.ac.com.pl/en (accessed on 10 May 2020).

47. Aleiferis, P.G.; Serras-Pereira, J.; Augoye, A.; Davies, T.J.; Cracknell, R.F.; Richardson, D. Effect of fuel temperature on innozzle cavitation and spray formation of liquid hydrocarbons and alcohols from a real-size optical injector for direct-injection spark-ignition engines. Int. J. Heat Mass Transf. 2010, 53, 4588-4606. [CrossRef]

48. Jang, C.; Kim, S.; Choi, S. An experimental and analytical study of the spray characteristics of an intermittent air-assisted fuel injector. At. Sprays 2000, 10, 199-217. [CrossRef]

49. Panão, M.R.O.; Moreira, A.L.N. Flow characteristics of spray impingement in PFI injection systems. Exp. Fluids 2005, 39, 364-374. [CrossRef] 
50. Borawski, A. Modification of a fourth generation LPG installation improving the power supply to a spark ignition engine. Eksploat. Niezawodn. 2015, 17, 1-6. [CrossRef]

51. Aleiferis, P.G.; Van Romunde, Z.R. An analysis of spray development with iso-octane, n-pentane, gasoline, ethanol and n-butanol from a multi-hole injector under hot fuel conditions. Fuel 2013, 105, 143-168. [CrossRef]

52. Leach, B.; Zhao, H.; Li, Y.; Ma, T. Two-phase fuel distribution measurements in a gasoline direct injection engine with an air-assisted injector using advanced optical diagnostics. Proc. Inst. Mech. Eng. Part D J. Automob. Eng. 2007, 221, 663-673. [CrossRef]

53. Serras-Pereira, J.; Aleiferis, P.G.; Walmsley, H.L.; Davies, T.J.; Cracknell, R.F. Heat flux characteristics of spray wall impingement with ethanol, butanol, iso-octane, gasoline and E10 fuels. Int. J. Heat Fluid Flow 2013, 44, 662-683. [CrossRef]

54. Walaszyk, A.; Busz, W. Application of optical method for the analysis delay between control injector coil and beginning of the fuel injection. Combust. Engines 2013, 154, 1038-1041.

55. Bor, M.; Borowczyk, T.; Karpiuk, W.; Smolec, R. Determination of the response time of new generation electromagnetic injectors as a function of fuel pressure using the internal photoelectric effect. In Proceedings of the 2018 International Interdisciplinary PhD Workshop, IIPhDW, Świnoujście, Poland, 9-12 May 2018; pp. 335-339.

56. Kakuhou, A.; Urushihara, T.; Itoh, T.; Takagi, Y. Characteristics of mixture formation in a direct injection SI engine with optimized in-cylinder swirl air motion. J. Engines 1999, 108, 550-558.

57. Robart, D.; Breuer, S.; Reckers, W.; Kneer, R. Assessment of pulsed gasoline fuel sprays by means of qualitative and quantitative laser-based diagnostic methods. Part. Part. Syst. Charact. 2001, 18, 179-189. [CrossRef]

58. Gao, H.; Zhang, F.; Zhang, Z.; Wang, E.; Liu, B. Experimental investigation on the spray characteristic of air-assisted hollow-cone gasoline injector. Appl. Therm. Eng. 2019, 151, 354-363. [CrossRef]

59. Spencer, A.; Brend, M.; Butcher, D.; Dunham, D.; Cheng, L.; Hollis, D. Tomographic PIV in the near field of a swirl-stabilised fuel injector. In Proceedings of the ASME Turbo Expo, Oslo, Norway, 11-15 June 2018; Volume 4A-2018.

60. Westerweel, J.; Scarano, F. Universal outlier detection for PIV data. Exp. Fluids 2005, 39, 1096-1100. [CrossRef]

61. Duncan, J.; Dabiri, D.; Hove, J.; Gharib, M. Universal outlier detection for particle image velocimetry (PIV) and particle tracking velocimetry (PTV) data. Meas. Sci. Technol. 2010, 21, 057002. [CrossRef]

62. Li, D.; Li, T.; Zhang, D. A monolithic piezoresistive pressure-flow sensor with integrated signal-conditioning circuit. IEEE Sens. J. 2011, 11, 2122-2128. [CrossRef]

63. Nawi, M.N.M.; Azeman, N.S.S.; Ab Razak, M.R. The effect of sensor structure and coplanar electrode for capacitive based flow sensor. Int. J. Recent Technol. Eng. 2019, 8, 4795-4799.

64. Chávez, A.; De Santiago, O. Determining a pressure response function of the hose and sensor arrangement for measurements of dynamic pressure in a dry gas seal film. Tribol. Int. 2020, 143, 106007. [CrossRef]

65. Bin Amari, M.D.; Shukor, M.S.B.A.; Abdullah, S.C. Optimization of velocity flap structures in high sensitivity macrofluidic airflow sensor. Int. J. Eng. Technol. 2018, 7, 11-15. [CrossRef]

66. Bochio, G.; Cely, M.M.H.; Teixeira, A.F.A.; Rodriguez, O.M.H. Experimental and numerical study of stratified viscous oil-water flow. AIChE J. 2021, 67, e17239. [CrossRef]

67. Guru Prasad, A.S.; Sharath, U.; Nagarjun, V.; Hegde, G.M.; Asokan, S. Measurement of temperature and pressure on the surface of a blunt cone using FBG sensor in hypersonic wind tunnel. Meas. Sci. Technol. 2013, 24, 095302. [CrossRef]

68. Schreiner, F.; Paepenmöller, S.; Skoda, R. 3D flow simulations and pressure measurements for the evaluation of cavitation dynamics and flow aggressiveness in ultrasonic erosion devices with varying gap widths. Ultrason. Sonochem. 2020, 67, 105091. [CrossRef]

69. Berberig, O.; Nottmeyer, K.; Mizuno, J.; Kanai, Y.; Kobayashi, T. The Prandtl micro flow sensor (PMFS): A novel silicon diaphragm capacitive sensor for flow-velocity measurement. Sensors Actuators A Phys. 1998, 66, 155-158. [CrossRef]

70. Corti, E.; Forte, C.; Cazzoli, G.; Moro, D.; Falfari, S.; Ravaglioli, V. Comparison of Knock Indexes Based on CFD Analysis. Energy Procedia 2016, 101, 917-924. [CrossRef]

71. Park, W.; Lee, J.; Min, K.; Yu, J.; Park, S.; Cho, S. Prediction of real-time NO based on the in-cylinder pressure in Diesel engines. Proc. Combust. Inst. 2013, 34, 3075-3082. [CrossRef]

72. Aravind, S.; Ragupathi, P.; Kumar, D.S.; Vignesh, G. A Numerical Investigation of Automotive Lambda Sensor to Improve the Life Span of the Sensor using CFD. In Proceedings of the IOP Conference Series: Materials Science and Engineering, Chennai, India, 20-21 February 2020; Volume 923, p. 012003.

73. Hurault, J.; Kouidri, S.; Bakir, F. Experimental investigations on the wall pressure measurement on the blade of axial flow fans. Exp. Therm. Fluid Sci. 2012, 40, 29-37. [CrossRef]

74. Mojarab, A.; Kamali, R. Design, optimization and numerical simulation of a MicroFlow sensor in the realistic model of human aorta. Flow Meas. Instrum. 2020, 74, 101791. [CrossRef]

75. Integrated Pressure Sensor MPXH6400A-Technical Data. Available online: https://www.nxp.com/docs/en/data-sheet/ MPXH6400A (accessed on 2 February 2020).

76. Valtek Type 30-Technical Data. Available online: https:/ /www.valtek.it (accessed on 2 February 2020).

77. Yang, Z.; Cheng, X.; Zheng, X.; Chen, H. Reynolds-Averaged Navier-Stokes Equations Describing Turbulent Flow and Heat Transfer Behavior for Supercritical Fluid. J. Therm. Sci. 2021, 30, 191-200. [CrossRef] 
78. Matyushenko, A.A.; Garbaruk, A.V. Adjustment of the k- $\omega$ SST turbulence model for prediction of airfoil characteristics near stall. J.Phys. Conf.Ser. 2016, 769, 012082. [CrossRef]

79. Spiegel, M.; Redel, T.; Zhang, J.J.; Struffert, T.; Hornegger, J.; Grossman, R.G.; Doerfler, A.; Karmonik, C. Tetrahedral vs. polyhedral mesh size evaluation on flow velocity and wall shear stress for cerebral hemodynamic simulation. Comput. Methods Biomech. Biomed. Engin. 2011, 14, 9-22. [CrossRef]

80. Michalcová, V.; Kotrasová, K. The numerical diffusion effect on the cfd simulation accuracy of velocity and temperature field for the application of sustainable architecture methodology. Sustainability 2020, 12, 10173. [CrossRef]

81. Zhang, H.; Tang, S.; Yue, H.; Wu, K.; Zhu, Y.; Liu, C.; Liang, B.; Li, C. Comparison of computational fluid dynamic simulation of a stirred tank with polyhedral and tetrahedral meshes. Iran. J. Chem. Chem. Eng. 2020, 39, 311-319.

82. Muigg, P.; Hadwiger, M.; Doleisch, H.; Gröller, E. Interactive volume visualization of general polyhedral grids. IEEE Trans. Vis. Comput. Graph. 2011, 17, 2115-2124. [CrossRef]

83. ANSYS Fluent Tutorial Guide 18. Available online: http:/ / ansys.fem.ir/ansys_fluent_tutorial.pdf (accessed on 2 February 2020).

84. Szpica, D.; Borawski, A.; Mieczkowski, G.; Kusznier, M.; Awad, M.M.; Sadik, A.M.; Sallah, M. Evaluation of the influence of the supply pressure on functional parameters of the impulse low-pressure gas-phase injector. Acta Mech. Autom. 2020, 14, 180-185. [CrossRef] 